\title{
Fire exposure behavior of epoxy reinforced with jute fiber applied to ceramic tiles for a ventilated facade system
}

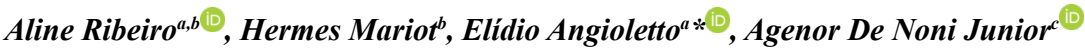 \\ aPrograma de Pós-Graduação em Ciência e Engenharia de Materiais - PPGCEM, Universidade do \\ Extremo Sul Catarinense - UNESC, Avenida Universitária 1.105, bairro Universitário, 88806-000, \\ Criciúma, SC, Brasil \\ ${ }^{b}$ Eliane S/A Revestimentos Cerâmicos, Rua Maximiliano Gaidzinski, 245, bairro Centro, 88845-000, \\ Cocal do Sul, SC, Brasil \\ 'Universidade Federal de Santa Catarina - UFSC, Campus Reitor João David Ferreira Lima, bairro \\ Trindade, 88040-900, Florianópolis, SC, Brasil
}

Received: December 09, 2018; Revised: April 17, 2019; Accepted: June 02, 2019

\begin{abstract}
Civil construction seeks to increase the useful life of the facades of buildings. Installing a ventilated facade is one way to accomplish this due to aesthetic and technical advantages. Ceramic tiles are the main products used as the covering. To the back face of a tile, a bidirectional screen of glass fiber is adhered using epoxy resin. This set forms a composite for security reasons. During the last decade, there has been an increase in the substitution of composites of synthetic fibers with those of natural fibers. The present work compares the fire-resistant behavior of glass fiber with that of jute fiber applied to ceramics installed in ventilated facade. The following conjoint composites were produced: glazed porcelain tile, epoxy resin, glass fiber and jute fiber screens. In this work, it was verified that the jute fiber did not present advantages regarding the exposure to fire in comparison with the glass fiber.
\end{abstract}

Keywords: Jute fiber, Composite, Ventilated facade, Exposure to fire.

\section{Introduction}

Architecture and civil construction seek sustainable solutions for the facades of buildings, and one of the motivations driving the search is the extension of the useful lives of buildings. One such solution is to use a ventilated facade due to its aesthetic and energy-efficient characteristics ${ }^{1}$. The main functional components of ventilated facades include: ceramic tiles, an auxiliary substructure, an air chamber, thermal insulation and a support base ${ }^{2,3}$. Fig. 1 shows a diagram of the ventilated facade components in comparison with those of the traditional adhered system.

The installation of the ventilated facade has a greater environmental impact when compared to that of the conventional facade because it uses aluminum profiles as supports. However, the gain in energy efficiency achieved over the lifetime of the building largely outweighs this difference. This makes the ventilated facade an environmentally advantageous solution ${ }^{1}$.

The main advantages of the ventilated facade in relation to the adhered facade include: energy efficiency; elimination of moisture problems, efflorescence or infiltration; reduction in maintenance costs of the facade and decreased deterioration; improvement in thermal/acoustic comfort and the elimination of the risk of detachment of ceramic tiles ${ }^{1}$.

In Spain, it was found that the gain in energy efficiency in ventilated facades is approximately $25 \%$ to $40 \%{ }^{1}$. It was

*e-mail: elidio@unesc.net.

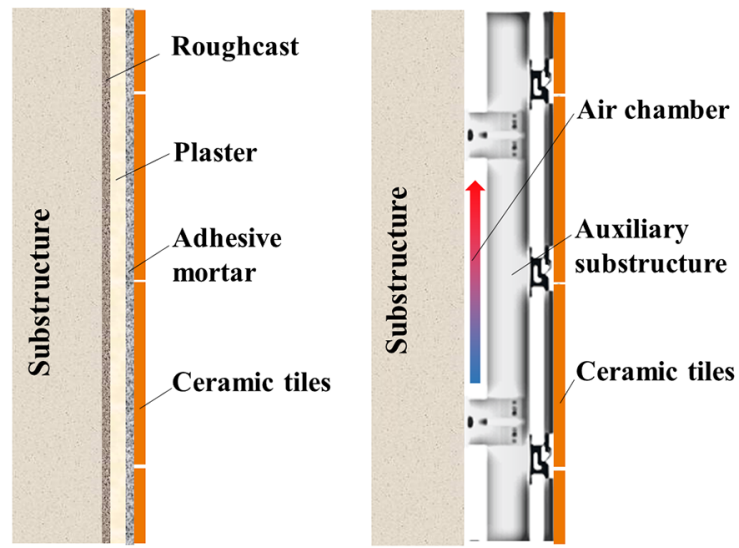

Figure 1. Representation of the models of ventilated facade and adhered facade.

also verified that the higher the thermal gradient is throughout the day, the greater the energy efficiency is with the use of the ventilated facade. From simulated studies, Bannier el al. ${ }^{4}$ state that the ventilated facade is suitable for hot areas and buildings that have a high demand for cooling. Previously, Escrig et al. ${ }^{5}$ found that the use of the ventilated facade is also effective in reducing the demand for heating (for facades with heat recovery).

According to Medeiros et al. ${ }^{6}$, the first projects in Brazil using this system of ventilated facades were carried out after the year 2000. However, after 2009, more than 80 projects were implemented, amounting to an expressive increase. 
One of the components of the ventilated facade system is the composite material constituted by a screen of glass fiber and polymeric resin adhered to a ceramic tile. The combination of these components aims to ensure the safety of the material after installation, thus avoiding the release of ceramic fragments from the facade of the building in case of the fracture of the ceramic tile. Throughout the lifetime and utilization of the building, there exists the possibility of chipping. This is a factor that must be taken into account regarding protection against shrapnel injuries that may occur due to fragmentation ${ }^{7}$.

Currently, the glazed porcelain tile is the most used ceramic tile on ventilated facades because it presents low porosity when compared to other ceramic tiles. This feature is associated with additional advantages, such as low water absorption, high mechanical performance and frost resistance ${ }^{7-9}$.

The reinforcement employed is usually a bidirectional screen composed of type E glass fiber. Glass fibers in the form of fabric increase the impact resistance of the system. When comparing glass fibers with other synthetic fibers (aramid, carbon, among others) with respect to structural function, glass represent the most attractive option due to low cost ${ }^{10-13}$. For this reason, glass is used in maritime, industrial, automotive and aerospace applications and is also found in everyday items ${ }^{14,15}$.

In the system composing the ventilated facade, epoxy resins are usually used. Among the main properties of these resins that are highlighted when compared to the properties of other polymers (polyester, vinyl ester and phenolic) are hardness, resilience, resistance to moisture and chemical attack, and little or no shrinkage after curing ${ }^{13}$. It should be noticed that this type of resin does not release volatile material during its application. If a curing agent or a thermal source is used, the curing process can be conducted at room temperature and without applying pressure ${ }^{16}$.

Resulting from the increase in environmental concern, there has been a growing interest in natural fibers. Polymeric composites containing natural fibers have been presented as substitutes for synthetic fiber composites in industrial applications. Among the advantages presented are weight reduction, higher specific strength, higher modulus of elasticity and reduced price ${ }^{14,17-25}$. The possible applications of the substitution of glass fibers have been studied in areas such as the automotive, aviation, biocomposites, civil construction, sports and musical instrument industries ${ }^{10,26-34}$. Especially in the automotive industry, natural fibers account for almost $40 \%$ of fiber raw materials ${ }^{35}$.

In recent years, several studies have been conducted to evaluate the various properties of natural fibers using epoxy matrix. Mittal et al. ${ }^{16}$ worked with fibers of bamboo, sisal, jute, silk, kenaf, sugar cane and coconut. Other authors such as Wambua et al. ${ }^{10}$ carried out comparative studies between natural fibers and glass and highlighted additional aspects such as recyclability, renewability, biodegradability, lower energy consumption for manufacturing and decreased inhalation health risks.

From the environmental point of view, natural fibers are superior to glass due to the following factors: reduced environmental impact in the production of fibers (because some of the processes occur naturally); lower composite weight; lower energy consumption in manufacturing processes; reduction of emissions and the possibility of end-of-life incineration, resulting in energy and carbon credits ${ }^{36}$.

In the Amazon region exist several natural fibers with the potential to be used. Among the natural fibers, jute fiber (Corchorus capsularis) can be highlighted. This fiber is obtained from the stem of the plant ${ }^{37}$. This plant was introduced in Brazil in the Amazon region after 1950. The cultivation of this plant occurs mainly in the states of Pará and São Paulo. Jute develops well in hot and humid climates, especially in areas where high rainfall occurs ${ }^{38-40}$.

Regarding the properties the jute fiber when compared to other natural fibers, jute presents moderate tensile and flexural strength. Already, the use of jute fiber in the manufacture of polymer composites is indicated for primary structural applications, interior elements and temporary outdoor applications. In automotive insulation, jute can be used in doors and roofs, engine separation panels and passenger compartments ${ }^{37}$. Jute is also traditionally used in the manufacture of bags, curtains, yarns, textiles, and ropes, among others ${ }^{41}$.

In the field of application chosen for this work, the facade of a building is an environment subject to several mechanical stresses and weather exposure. With the increasing use of ventilated facades, there exists a tendency to utilize large formats of ceramic tiles with reduced thicknesses. Among the properties of ceramic materials that are used in ventilated facades, impact resistance is one of the most critical characteristics to be observed ${ }^{41,42}$.

As an alternative to glass fiber composites in structures that require impact protection and, consequently, the occurrence of kinetic energy absorption, the use of natural fibers presents a wide range of applications ${ }^{19}$. Among these applications is the absorption of both ballistic and low-speed energy. Under low-speed impact conditions, the natural fibers behave similarly to glass fibers and the properties of both demonstrate similar values ${ }^{18}$.

The combustibility of natural fiber-polymer composites depends mainly on the type of raw materials used, structure, composite density, thermal conductivity and humidity. Thermal properties of these materials are dependent on the characteristics of the natural fibers, the matrix and the interactions between them ${ }^{24}$. Vaisanen et al. ${ }^{24}$ state that the combustion stages for natural fiber-polymer composites are: ignition, smoldering, developing fire, flashover, fully developed fire and decay. Szolnoki et al. ${ }^{20}$ state that natural fiber-polymer composites are flammable and that the release 
of heat from these composites is greater than that experienced when using synthetic fibers.

Depending on the application, natural fiber-polymer composites must undergo fire exposure tests due to low fire resistance and smoke generation. Polymers suitable for use in natural fiber-polymer composites are limited due to thermal degradation of the fibers starting from approximately 200 ${ }^{\circ} \mathrm{C}{ }^{24}$. In real fire condition the maximum temperature can reach $1000^{\circ} \mathrm{C}^{43}$.

This work proposes to evaluate the substitution of glass fiber by natural jute fiber. Due to the conditions of installation of the ventilated facade, the behavior of the conjoint composites when exposed to fire were studied. For that, the characteristics of these materials were evaluated through thermogravimetry together with differential thermal analysis and the exhaust gases analyzed. For the conjoint composites the flame propagation was observed.

\section{Materials and Methods}

\subsection{Materials}

The materials that were used in the preparation of the final systems included: glazed porcelain tiles were supplied by Eliane S/A Revestimentos Cerâmicos (Brazil) and had a size of $0.59 \mathrm{~m} \mathrm{x} 1.182 \mathrm{~m}$ and a thickness of $0.012 \mathrm{~m}$. The resin used was supplied by Shackerley (United Kingdom). The bicomponent epoxy resin was derived from bisphenol A and amines (DGEBA). The fiberglass used was bidirectional screen type E. This fiber is commonly used in ventilated facades. This was supplied by Gavazzi (Italy). The fiberglass screen had dimensions of $0.004 \mathrm{~m} \times 0.0045 \mathrm{~m} \times 0.0003 \mathrm{~m}$. For natural fiber a bidirectional screen similar in configuration to that of the fiberglass screen pattern was used. However, the lowest thickness found in the market was approximately $0.008 \mathrm{~m}$ (while the fiberglass has a thickness of approximately $0.0003 \mathrm{~m}$ ). This fiber is $20 \%$ lighter than fiberglass. It was supplied by Companhia Têxtil Castanhal of the state of Pará (Brazil). A plasticizer based on the esters of acrylic acid and styrene was used to perform the compatibilization between the polymer matrix and natural fiber. This product is a binder for elastomeric coatings used in facades. After compatibilization, jute fiber became $66 \%$ heavier relative to glass fiber. This plasticizer was supplied by Claritex (Brazil). The plasticizer had a solid content of $50 \%$ and viscosity between $3.0 \mathrm{~kg} \cdot \mathrm{m}^{-1} \cdot \mathrm{s}^{-1}$ and $5.0 \mathrm{~kg} \cdot \mathrm{m}^{-1} \cdot \mathrm{s}^{-1}$.

\subsection{Preparation of test specimens}

The following steps were developed for the realization of the conjoint composite glass (Cer+GFRE) and jute fibers (Cer+JFRE). The glazed porcelain tiles were cut into 0.30 $\mathrm{m} \times 0.30 \mathrm{~m}$ sections with an industrial cutting machine. The screens (glass and natural) were cut according to the size of the cut ceramic tiles. The screens were cut with the assistant of a sharp object. A plasticizer was applied with a sheepskin roll to the natural fiber only. The plasticizer layer deposited on the fiber corresponded to a value of $0.280 \mathrm{~kg} \cdot \mathrm{m}^{-2}$. The drying process took place in a ventilated environment at room temperature for $24 \mathrm{~h}$ for subsequent application to the system. The epoxy resin was applied with a brush and metal spatula. The resin mixture and the curing agent were applied according to the supplier's procedure $(82 \%$ resin and $18 \%$ curing agent under stirring). The resin layer had a value of approximately $0.50 \mathrm{~kg} \cdot \mathrm{m}^{-2}$. For the final composites, the screen was inserted into the polymer matrix during the application of the epoxy resin. Curing was performed in a ventilated environment at room temperature for $72 \mathrm{~h}$. After the curing process was completed $(72 \mathrm{~h})$, the specimens were cut to the required dimensions for each test following the current standard. After cutting, the specimens were ovendried at a temperature of $40{ }^{\circ} \mathrm{C}$ to a constant weight. After drying, the specimens were stored in a place protected from light and moisture.

\section{Test Methodology}

Thermal analysis was separately performed on epoxy resin, glass fiber and jute fiber. A sample of the materials for analysis was taken (glass fiber, jute fiber and epoxy after curing). Netzch model STA 449F3 with coupling to a Fourier transform infrared spectroscopy equipment was used. The gas employed was synthetic air with the test running from 25 ${ }^{\circ} \mathrm{C}$ to $1100{ }^{\circ} \mathrm{C}$ with a heating rate of $10^{\circ} \mathrm{C} / \mathrm{min}$. The crucible for sample placement was alumina $\left(\mathrm{Al}_{2} \mathrm{O}_{3}\right)$. The synthetic air was chosen to simulate the behavior of the composite constituents during the application of fire exposure. The gases expelled from the thermogravimetric analysis were analyzed through Fourier transform infrared spectroscopy.

The flame propagation test was performed based on standards NBR 9442 (determination of the flame surface propagation index by the radiant panel method) and ASTM E 84 (standard test method for surface burning characteristics of building materials).

The conjoint composite was placed under a $60^{\circ}$ tilt through a metal support. The flame was positioned in parallel, 0.10 meters from the edge of the ceramic tile and 0.02 meters away from the sample. To generate the flame, a torch was used with fuel representing the proportion of $50 \%$ oxygen gas and 50\% acetylene gas. In Figure 2, a representation of the scheme used in the flame propagation test is displayed.

During the experimental execution, the presence or absence of several phenomena were observed, including: dripping of the burning material, detachment of the material, sagging, delamination, contraction, fracture and formation of ashes. Also determined was the time required for ignition, the maximum temperature reached, the flame advancement and the color of the developed smoke. For the measurement of temperature, a Minipa model MT-350 optical pyrometer was utilized. 
a)

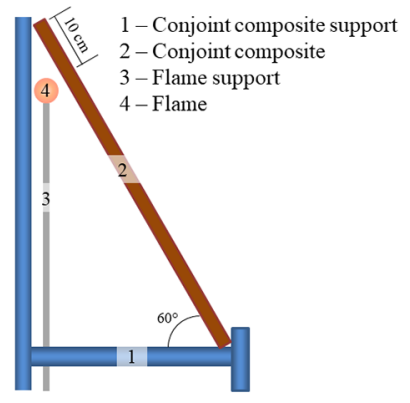

b)

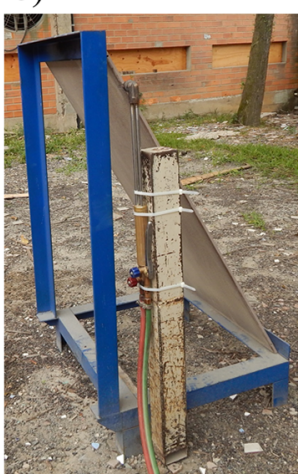

Figure 2. a) Schematic representation of the apparatus for the test. b) Photograph of the apparatus for the test.

\section{Results and Discussion}

\subsection{Thermal analysis of epoxy resin}

Figure 3 shows the thermogravimetric and differential thermal analysis of the epoxy resin. It can be seen that the total mass loss of the epoxy resin is $53.96 \%$, primarily occurring between $115{ }^{\circ} \mathrm{C}$ and $736^{\circ} \mathrm{C}$. There are three exothermic events located at $188^{\circ} \mathrm{C}, 334^{\circ} \mathrm{C}$ and $714^{\circ} \mathrm{C}$.

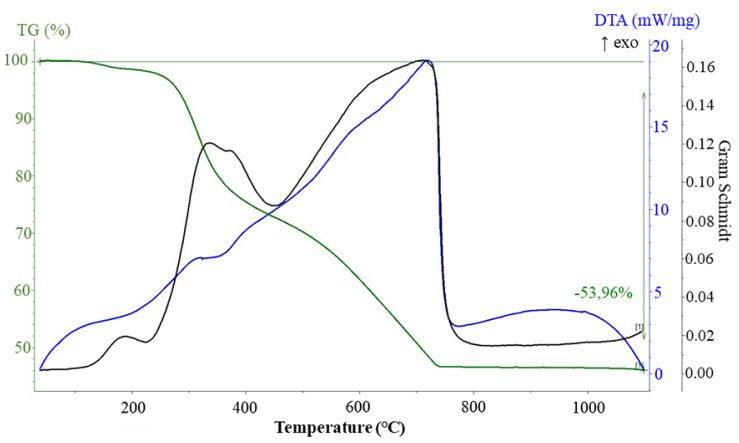

Figure 3. Thermogravimetric and differential thermal analysis of the epoxy resin.

According to Abdellaoui et al. ${ }^{31}$, thermoset matrices may contain mineral fillers, with the objective of reducing costs and improving thermal and mechanical properties of the final composite. The epoxy resin of this study was supplied with mineral filler. Thus, the residual mass of the thermogravimetric analysis is mainly related to the filler.

Figure 4 shows the result of the FTIR analysis of the set of gases resulting from the thermal decomposition of the epoxy resin. The main associated bands are carbon dioxide $\left(\mathrm{CO}_{2}\right)$ and the lower bands of chemical composition of the epoxy resin (curing agent). Table 1 shows the compounds present in the gases during the analysis. During thermal decomposition and the oxidation of the resin, the thermal events are associated with the formation and the output of different types of gases. According to Kim et al. ${ }^{44}$ polymer matrix decomposes at $300-500{ }^{\circ} \mathrm{C}$ producing smoke with dripping which may be toxicity.

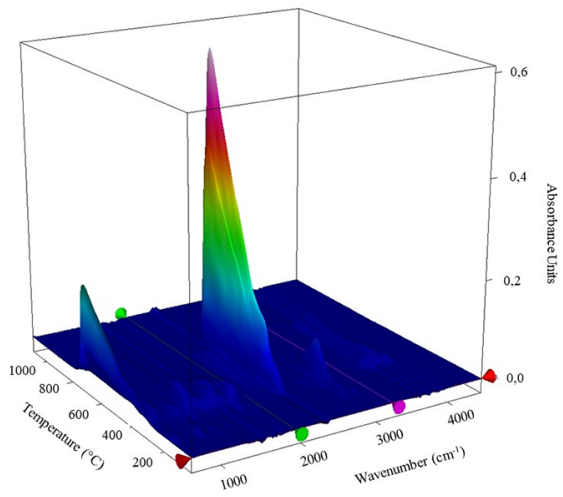

Figure 4. Infrared gas spectrum resulting from the thermal analysis of the epoxy resin.

\subsection{Thermal analysis of glass fiber screen}

Figure 5 shows the differential thermogravimetric and thermal analysis of glass fiber. The total mass loss of the fiber is $19.23 \%$, occurring from $220^{\circ} \mathrm{C}$ to $610{ }^{\circ} \mathrm{C}$. There are three events, one endothermic and two exothermic. The endothermic event occurs at $173{ }^{\circ} \mathrm{C}$, and the exothermic events are observed at $441{ }^{\circ} \mathrm{C}$ and $590^{\circ} \mathrm{C}$.

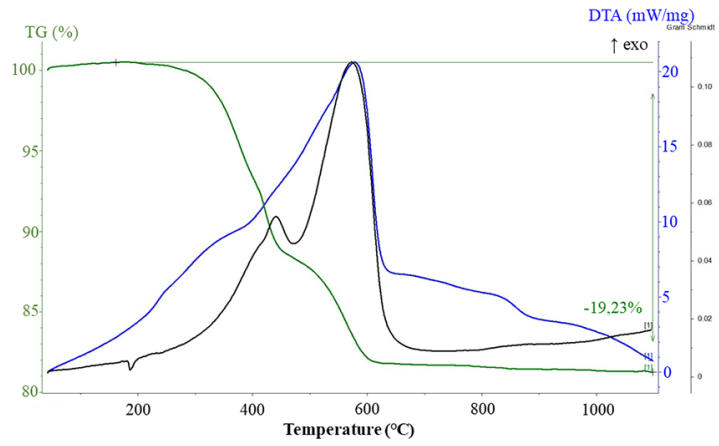

Figure 5. Thermogravimetric and differential thermal analysis of glass fiber.

According to Neto et al. ${ }^{45}$, the glass fibers are covered with coating materials after the spinning process. These materials are usually organosilanes whose objective is to promote chemical adhesion between the polymer matrix and the fiber surface. The fiber used underwent a polymer coating (approximately $18 \% \mathrm{w}$ ), adapting it to environments 
Table 1. Compounds present in the resulting gas at each thermal event of the thermal analysis of the epoxy resin.

\begin{tabular}{|c|c|c|c|}
\hline Temperature $\left({ }^{\circ} \mathrm{C}\right)$ & Compound in the resulting gas & Molecular formula & Wavenumber $\left(\mathrm{cm}^{-1}\right)$ \\
\hline 188 & Benzyalcohol & $\mathrm{C}_{7} \mathrm{H}_{8} \mathrm{O}$ & 1050 and 3050 \\
\hline 334 & $\begin{array}{l}\text { N-dodecyl benzamine } \\
\text { 2-decanone }\end{array}$ & $\begin{array}{l}\mathrm{C}_{18} \mathrm{H}_{31} \mathrm{~N} \\
\mathrm{C}_{10} \mathrm{H}_{20} \mathrm{O}\end{array}$ & $\begin{array}{l}1500 \text { and } 3000 \\
1700 \text { and } 2950\end{array}$ \\
\hline 714 & carbon dioxide & $\mathrm{CO}_{2}$ & 2350 \\
\hline
\end{tabular}

that require resistance to alkaline corrosion. Thus, the mass loss resulting from the thermogravimetric analysis corresponds mainly to the disappearance of the coating of the fibers.

In Figure 6 is displayed the infrared spectrum of the gases resulting from the thermal analysis of glass fiber. For this material, the only gas identified in the gas resulting from the decomposition of the coating material is carbon dioxide $\left(\mathrm{CO}_{2}\right)$.

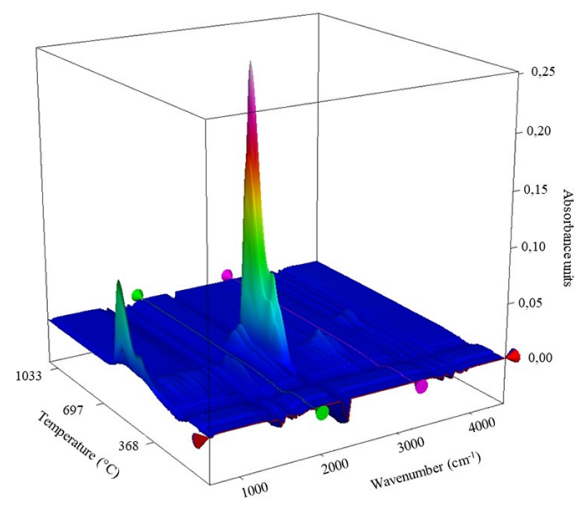

Figure 6. Infrared spectrum of gases resulting from thermal analysis of glass fiber.

\subsection{Thermal analysis of jute fiber screen}

Figure 7 shows the thermogravimetric and thermal differential analysis of the natural jute fiber.

According to Figure 7, the total weight loss of the jute fiber is $87.77 \%$, occurring from $40{ }^{\circ} \mathrm{C}$ to $580^{\circ} \mathrm{C}$. There are three exothermic events occurring at $309^{\circ} \mathrm{C}, 361^{\circ} \mathrm{C}$ and $574{ }^{\circ} \mathrm{C}$. These thermal events are associated with the decomposition of hemicellulose, cellulose and lignin, respectively ${ }^{46}$.

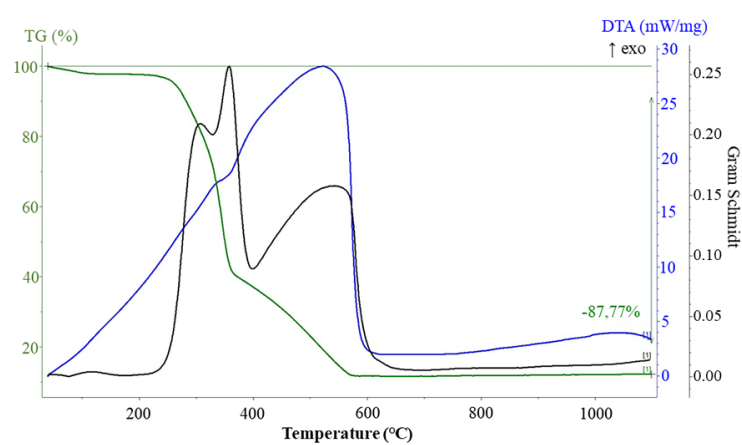

Figure 7. Thermogravimetric and differential thermal analysis of jute fiber.

Because it is a natural fiber, the residual mass was much lower in comparison to epoxy resin and glass fiber. In Figure 8 is the infrared spectrum of the gases resulting from the thermal analysis of jute fiber. Because jute fiber is natural, the spectrum contains several bands resulting from the release of organic compounds. The compounds methanol, octanoic acid, and methyl butanoate are associated with the presence of lignin, while the others are the result of hemicellulose and cellulose. However, the main band represents the presence of carbon dioxide $\left(\mathrm{CO}_{2}\right)$. According to literature data ${ }^{47}$, the toxicity caused by the inhalation of compounds found (Table 2), acts on the central nervous system in addition to harmful respiratory effects.

Although the literature indicates that natural fibers are non-toxic ${ }^{48}$ and the resulting product of combustion is formed with carbon dioxide, the results obtained indicated the presence of other organic compounds. Further studies on the toxicity of jute fiber in fire conditions should be

Table 2. Compounds present in the resulting gas at each thermal event of the jute fibre thermal analysis.

\begin{tabular}{|c|c|c|c|}
\hline Temperature $\left({ }^{\circ} \mathrm{C}\right)$ & Compound in the resulting gas & Molecular formula & Wavenumber $\left(\mathrm{cm}^{-1}\right)$ \\
\hline 309 & $\begin{array}{c}\text { methanol } \\
\text { carbon dioxide } \\
\text { octanoic acid } \\
\text { methyl butanoate } \\
\text { water }\end{array}$ & $\begin{array}{c}\mathrm{CH}_{4} \mathrm{O} \\
\mathrm{CO}_{2} \\
\mathrm{C}_{8} \mathrm{H}_{16} \mathrm{O}_{2} \\
\mathrm{C}_{5} \mathrm{H}_{10} \mathrm{O}_{2} \\
\mathrm{H}_{2} \mathrm{O}\end{array}$ & $\begin{array}{c}1030 \\
2350 \\
2950 \text { and } 1700 \\
2850 \\
3700\end{array}$ \\
\hline 361 & $\begin{array}{l}\text { octanoic acid } \\
\text { methyl butanoate } \\
\text { carbon dioxide }\end{array}$ & $\begin{array}{l}\mathrm{C}_{8} \mathrm{H}_{16} \mathrm{O}_{2} \\
\mathrm{C}_{5} \mathrm{H}_{10} \mathrm{O}_{2} \\
\mathrm{CO}_{2}\end{array}$ & $\begin{array}{c}2950 \text { and } 1700 \\
2850 \\
2350\end{array}$ \\
\hline 574 & carbon dioxide & $\mathrm{CO}_{2}$ & 2350 \\
\hline
\end{tabular}




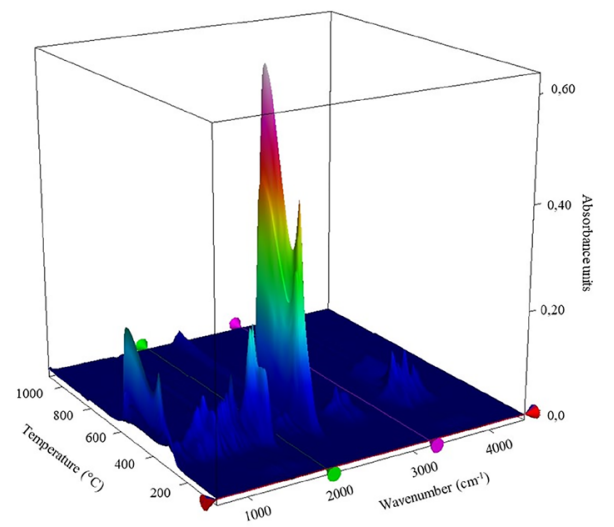

Figure 8. Infrared spectrum of gases resulting from the thermal analysis of jute fiber.

performed. Table 2 shows the compounds present in the gases during differential thermal analysis.

\subsection{Flame propagation}

In the flame propagation test conducted, there was no flame propagation throughout the sample, only the carbonization of the epoxy resin, consumption of the glass fiber polymer layer and partial consumption of the jute fiber in the region of exposure to flame were observed. Table 3 shows the phenomena observed during the flame propagation test.

According to Table 3, the only phenomenon observed that demonstrated a differential result among the samples was in relation to the formation of ashes. Although there was no smoke formation, the jute fiber composite exhibited the formation and evolution of ash during the test. Table 4 shows the other measured parameters observed during the test.

For both samples, the ignition time was immediate; however, the flame on the surface of the material was soon extinguished. The maximum temperature observed and the time required for the occurrence of ceramic tile fracture were similar regardless of the nature of the fibers.

The area damaged by the flame was larger for the case of the jute fiber. Figure 9 shows the initial instants where it was possible to observe the formation of flame on the surface of the material during the test.

In Figure 10, it is possible to observe the differences in damage caused by the flame to the conjoint composites. As shown in Table 4, the flame advancement was more extensive in the jute fiber set, and it was possible to observe in Figure 8 that near-total consumption of jute fiber occurred in some regions. Although jute fiber is encased by epoxy resin, this is not sufficient to protect natural fiber from fire.

During the test, the ceramic tile fracture occurred in the region where the flame was positioned. Despite the fact that the epoxy resin and the polymer layer were consumed, the tested glass fiber still performed its function, avoiding the release of fragments. However, for the jute fiber composite, much of the fiber was consumed by the flame (a result that correlates with the thermogravimetric analysis): the jute fiber failed to perform its function, thus resulting in the release of ceramic fragments during the test. Figure 11 shows the fracture behavior observed during the flame propagation test.

Table 3. Phenomena observed in the flame propagation test

\begin{tabular}{ccc}
\hline Observed Phenomenon & Cer+GFRE & Cer+JFRE \\
\hline Dripping of burning material & No & No \\
Discharge of burning material & No & No \\
Sagging of material & No & Yes \\
Observed delamination & Yes & No \\
Observed contraction & No & Yes \\
Fracture observed & Yes & Yes \\
Ashes observed & No & Did not occur \\
Smoke color development & Did not occur & \\
\hline
\end{tabular}

Table 4. Parameters observed in the flame propagation test

\begin{tabular}{ccc}
\hline Parameter observed & Cer+GFRE & Cer+JFRE \\
\hline Ignition time & Immediate & Immediate \\
Maximum temperature reached $\left({ }^{\circ} \mathrm{C}\right)$ & 528 & 529 \\
Time for fracture $(s)$ & 257 & 269 \\
Flame advance $(m)$ & $0.13 \times 0.44$ & $0.17 \times 0.53$ \\
Total test time $(s)$ & 300 & 300 \\
\hline
\end{tabular}



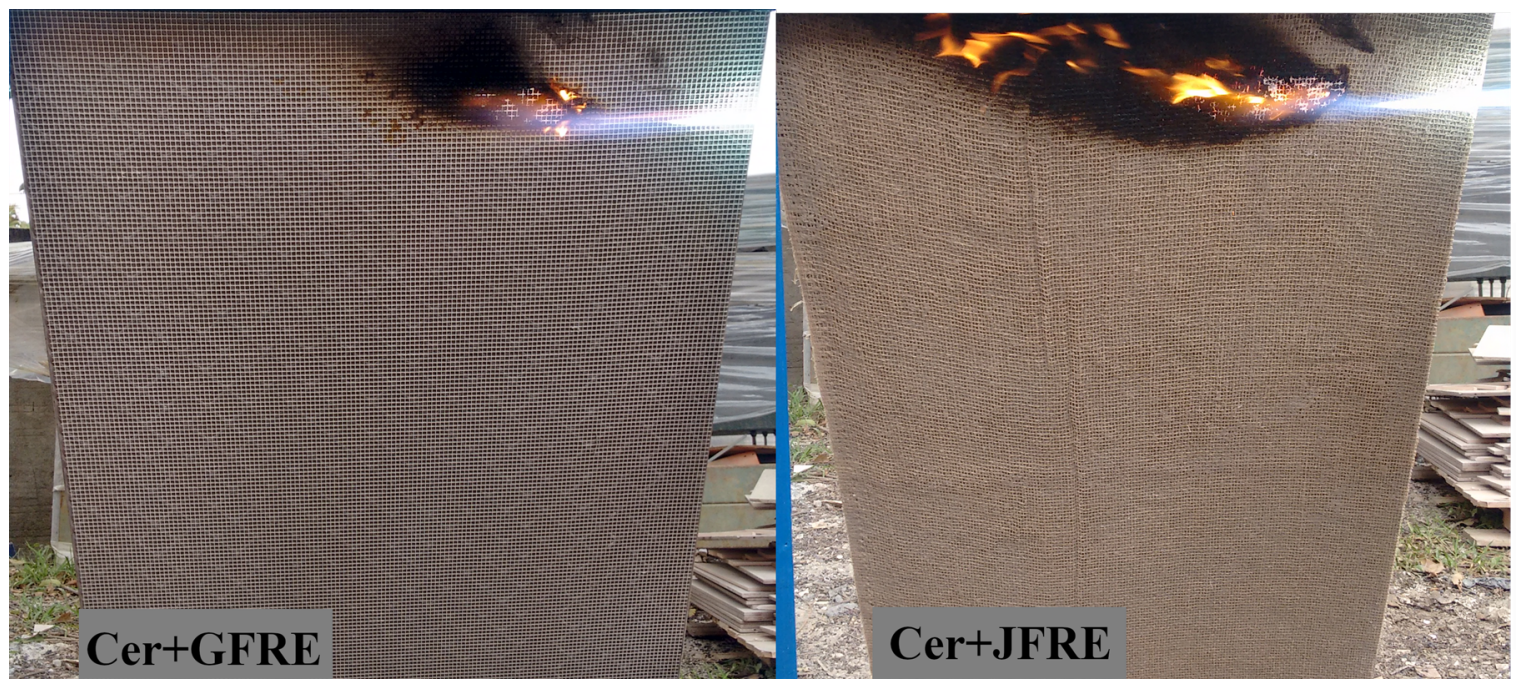

Figure 9. Initial moments in the flame propagation test.

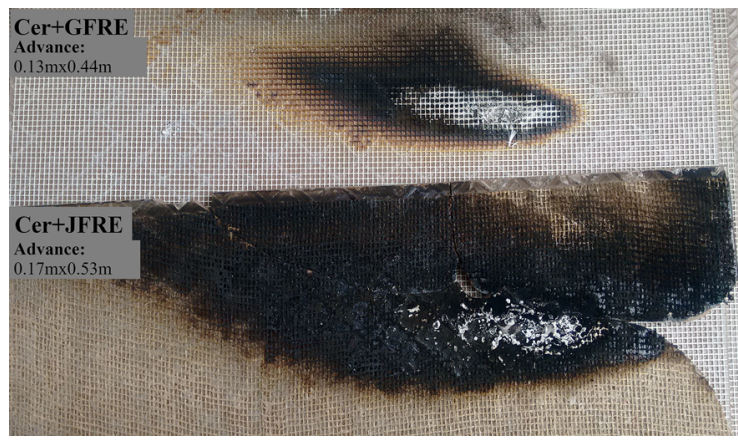

Figure 10. Comparison of the conjoint composites after the flame propagation test.

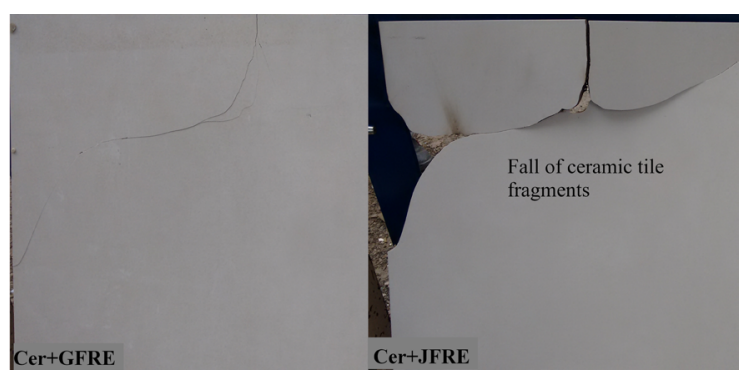

Figure 11. Fracture of the ceramic tile during the flame propagation test.

\section{Conclusions}

The application of a jute fiber composite was evaluated in a ventilated facade in comparison to that of a current glass fiber system in terms of exposure to a thermal energy source.

The residual mass of the epoxy resin, resulting from the thermogravimetric analysis, refers to the mineral filler used. The loss of mass of the glass fiber in this same analysis is related mainly to the polymer layer applied on the fiber. From the materials tested in the thermogravimetric analysis, the jute fiber showed the greatest mass loss due to the origin of the fiber. This feature may compromise the performance of the conjoint composite in the occurrence of fire.

Regarding the application to fire exposure, the conjoint composite jute fiber (Cer + JFRE) presented the worst performance in this study. Due to the origin and composition of the fiber, the material was consumed by the flames and was not capable of exerting its function of retaining the pieces in the set after the fracture of the ceramic tile. For this reason, the jute fibers present limitations regarding application to a ventilated facade without the use of flame retardant.

\section{References}

1. Ruá MJ, Vives L, Civera V, López-Mesa B. Aproximación al cálculo de la eficiencia energética de fachadas ventiladas y su impacto ambiental. In: Congresso Mundial de la Calidad del Azulejo y Del Pavimento Cerâmico - QUALICER 2010; 2010 Feb 15-16; Castellón; Spain. 15 p.

2. Müller A, Alarcon OE. Desenvolvimento de um sistema de fachada ventilada com placas cerâmicas de grês porcelanato voltado para a construção civil do Brasil. Cerâmica. 2005;51(320):354-360.

3. Campos KF. Desenvolvimento de Sistema de Fixação de Fachada Ventilada com Porcelanato de Fina Espessura. [Dissertation]. Florianópolis: Federal University of Santa Catarina; 2011.

4. Bannier E, Cantavella V, Silva G, Pinazo JM, Soto VM, Sarabia E. Contribution of the Ventilated Façade to Building Energy Demand. In: Congresso Mundial de la Calidad del Azulejo y Del Pavimento Cerâmico - QUALICER 2012; 2012 Feb 13-14; Castellón; Spain. 15 p.

5. Escrig A, Bannier E, Bou E, Cantavella V, Corrales J. Cuantificación de la Mejora de la Eficiencia Energética de Edificios con Sistemas Innovadores Basados en Fachadas Ventiladas. In: Congresso Mundial de la Calidad del Azulejo y Del Pavimento Cerâmico - QUALICER 2014; 2014 Feb 17-18; Castellón; Spain. 13 p. 
6. Medeiros JS, Yoshida R, Carraro M, Asamura RE, Rebeschin MF. Ingeniería Arquitectónica de las Fachadas Cerámicas Ventiladas: Diseño, Comportamiento y Mercado en Brasil. In: Congresso Mundial de la Calidad del Azulejo y Del Pavimento Cerâmico - QUALICER 2016; 2016 Feb 8-9; Castellón; Spain. $12 \mathrm{p}$.

7. Álvaro Guzmán A, Marisol Gordillo S, Silvio Delvasto A, María Francisca Quereda V, Enrique Sánchez V. Optimization of the technological properties of porcelain tile bodies containing rice straw ash using the design of experiments methodology. Ceramics International. 2016;42(14):15383-15396.

8. Sánchez E, García-Ten J, Sanz V, Moreno A. Porcelain tile: Almost 30 years of steady scientific-technological evolution. Ceramics International. 2010;36(3):831-845.

9. Dal Bó M, Dominguini L, Zimmer A, Grando SR, Kaspari P, Hotza D. Chemical tempering of porcelain tiles. Ceramics International. 2016;42(14):15199-15202.

10. Wambua P, Ivens J, Verpoest I. Natural fibres: can they replace glass in fibre reinforced plastics? Composites Science and Technology. 2003;63(9):1259-1264.

11. Meola C, Carlomagno GM. Infrared thermography to evaluate impact damage in glass/epoxy with manufacturing defects. International Journal of Impact Engineering. 2014;67:1-11.

12. Simeoli G, Acierno D, Meola C, Sorrentino L, Iannace S, Russo $\mathrm{P}$. The role of interface strength on the low velocity impact behaviour of $\mathrm{PP} /$ glass fibre laminates. Composites Part B: Engineering. 2014;62:88-96.

13. Ma HL, Jia Z, Lau KT, Leng J, Hui D. Impact properties of glass fiber/epoxy composites at cryogenic environment. Composites Part B: Engineering. 2016;92:210-217.

14. Ramesh M, Palanikumar K, Reddy KH. Mechanical property evaluation of sisal-jute-glass fiber reinforced polyester composites. Composites Part B: Engineering. 2013;48:1-9.

15. Sebaey TA, Mahdi E. Crashworthiness of pre-impacted glass/ epoxy composite tubes. International Journal of Impact Engineering. 2016;92:18-25.

16. Mittal V, Saini R, Sinha S. Natural fiber-mediated epoxy composites - A review. Composites Part B: Engineering. 2016;99:425-435.

17. Dhakal HN, Zhang ZY, Bennett N, Reis PNB. Low-velocity impact response of non-woven hemp fibre reinforced unsaturated polyester composites: Influence of impactor geometry and impact velocity. Composite Structures. 2012;94(9):2756-2763.

18. Meredith J, Ebsworth R, Coles SR, Wood BM, Kirwan K. Natural fibre composite energy absorption structures. Composites Science and Technology. 2012;72(2):211-217.

19. Caprino G, Carrino L, Durante M, Langella A, Lopresto V. Low impact behaviour of hemp fibre reinforced epoxy composites. Composite Structures. 2015;133:892-901.

20. Szolnoki B, Bocz K, Sóti PL, Bodzay B, Zimonyi E, Toldy A, et al. Development of natural fibre reinforced flame retarded epoxy resin composites. Polymer Degradation and Stability. 2015;119:68-76.
21. Vimal R, Subramanian KHH, Aswin C, Logeswaran V, Ramesh M. Comparisonal Study of Succinylation and Phthalicylation of Jute Fibres: Study of Mechanical Properties of Modified Fibre Reinforced Epoxy Composites. MaterialsToday: Proceedings. 2015;2(4-5):2918-2727.

22. Jabbar A, Militký J, Kale BM, Rwawiire S, Nawab Y, Baheti V. Modeling and analysis of the creep behavior of jute/green epoxy composites incorporated with chemically treated pulverized nano/ micro jute fibers. Industrial Crops and Products. 2016;84:230240.

23. Khan Z, Yousif BF, Islam M. Fracture behaviour of bamboo fiber reinforced epoxy composites. Composites Part B: Engineering. 2017;116:186-199.

24. Väisänen T, Das O, Tomppo L. A review on new bio-based constituents for natural fiber-polymer composites. Journal of Cleaner Production. 2017;149:582-596.

25. Yu T, Tuerhongjiang T, Sheng C, Li Y. Phosphorus-containing diacid and its application in jute/poly(lactic acid) composites: Mechanical, thermal and flammability properties. Composites Part A: Applied Science and Manufacturing. 2017;97:60-66.

26. Zah R, Hischier R, Leão AL, Braun I. Curauá fibers in the automobile industry - a sustainability assessment. Journal of Cleaner Production. 2007;15(11-12):1032-1040.

27. Ho MP, Wang H, Lee JH, Ho CK, Lau KT, Leng J, et al. Critical factors on manufacturing processes of natural fibre composites. Composites Part B: Engineering. 2012;43(8):3549-3562.

28. Phillips S, Lessard L. Application of natural fiber composites to musical instrument top plates. Journal of Composite Materials. 2012;46(2):145-154.

29. Frollini E, Bartolucci N, Sisti L, Celli A. Biocomposites based on poly(butylene succinate) and curaua: Mechanical and morphological properties. Polymer Testing. 2015;45:168-173.

30. Claramunt J, Fernández-Carrasco LJ, Ventura H, Ardanuy M. Natural fiber nonwoven reinforced cement composites as sustainable materials for building envelopes. Construction and Building Materials. 2016;115:230-239.

31. Abdellaoui H, Bensalah H, Raji M, Rodrigue D, Bouhfid R, Qaiss AEK. Laminated Epoxy Biocomposites Based on Clay and Jute Fibers. Journal of Bionic Engineering. 2017;14(2):379389.

32. Arpitha GR, Yogesha B. An Overview on Mechanical Property Evaluation of Natural Fiber Reinforced Polymers. MaterialsToday: Proceedings. 2017;4(2 Pt A):2755-2760.

33. Bansal S, Ramachandran M, Raichurkar P. Comparative Analysis of Bamboo using Jute and Coir Fiber Reinforced Polymeric Composites. MaterialsToday: Proceedings. 2017;4(2 Pt A):3182-3187.

34. Deb A, Das S, Mache A, Laishram R. A Study on the Mechanical Behaviors of Jute-polyester Composites. Procedia Engineering. 2017;173:631-638.

35. Adekomaya O, Jamiru T, Sadiku R, Huan Z. Negative impact from the application of natural fibers. Journal of Cleaner Production. 2017;143:843-846. 
36. Joshi SV, Drzal LT, Mohanty AK, Arora S. Are natural fiber composites environmentally superior to glass fiber reinforced composites? Composites Part A: Applied Science and Manufacturing. 2004;35(3):371-376.

37. Bisaria H, Gupta MK, Shandilya P, Srivastava RK. Effect of Fibre Length on Mechanical Properties of Randomly Oriented Short Jute Fibre Reinforced Epoxy Composite. MaterialsToday: Proceedings. 2015;2(4-5):1193-1199.

38. Satyanarayana KG, Guimarães JL, Wypych F. Studies on lignocellulosic fibers of Brazil. Part I: Source, production, morphology, properties and applications. Composites Part A: Applied Science and Manufacturing. 2007;38(7):1694-1709.

39. Jahan MS, Rahman JNMM, Islam M, Quaiyyum MA. Chemical characteristics of ribbon retted jute and its effect on pulping and papermaking properties. Industrial Crops and Products. 2016;84:116-120.

40. Mansourian A, Razmi A, Razavi M. Evaluation of fracture resistance of warm mix asphalt containing jute fibers. Construction and Building Materials. 2016;117:37-46.

41. Silva Moreno G, Muñoz A, Felíu Mingarro C, Cantavella Soler V. Comportamiento Mecánico Frente al Impacto de Baldosas Cerámicas. In: Congresso Mundial de la Calidad del Azulejo y Del Pavimento Cerâmico - QUALICER 2002; 2002 Mar 3-6; Castellón, Spain; 2002. p. 385-399.

42. Dondi M, Guarini G, Melandri C, Raimondo M, Zanelli C. Resistance to impact of porcelain stoneware tiles. Ceramics International. 2016;42(5):5731-5736.

43. Silva VP. Projeto de Estruturas de Concreto em Situação de Incêndio: Conforme ABNT NBR 15200:2012. $1^{\mathrm{a}}$ ed. São Paulo: Blucher; 2012. $238 \mathrm{p}$.

44. Kim NK, Dutta S, Bhattacharyya D. A review of flammability of natural fibre reinforced polymeric composites. Composites Science and Technology. 2018;162:64-78.

45. Levy Neto F, Pardini LC. Compósitos Estruturais: Ciência e Tecnologia. $1^{\text {a }}$ ed. São Paulo: Blucher; 2006. 336 p.

46. Yang H, Yan R, Chen H, Zheng C, Lee DH, Liang DT. In-Depth Investigation of Biomass Pyrolysis Based on Three Major Components: Hemicellulose, Cellulose and Lignin. Energy \& Fuels. 2006;20(1):388-393.

47. Micromedex. International Healthcare Series. Armonk: IBM; 1999.

48. Joseph K, Tolêdo Filho RD, James B, Thomas S, de Carvalho LH. A Review on Sisal Fiber Reinforced Polymer Composites. Revista Brasileira de Engenharia Agrícola e Ambiental. 1999;3(3):367-379. 